\title{
COMMENTS
}

\section{Class-Based Preferences in Affirmative Action Programs After Miller $v$ Johnson: A Race-Neutral Option, or Subterfuge?}

\author{
Chapin Cimino†
}

It is not news that race-based preferences in affirmative action programs are unpopular. Scholars assail these preferences as divisive, stigmatizing, and harmful to "innocent victims." Recently, in Adarand Constructors, Inc $v$ Pena, the Supreme Court declared that all racial classifications, whether benign or invidious, are subject to strict scrutiny. ${ }^{2}$ Nonetheless, the Court recognizes that racial discrimination still exists, and that there is a role, albeit limited, for government in combating this problem. ${ }^{3}$ The Court has repeatedly suggested that this limited role might emerge in the form of "race-neutral" alternatives to race-based preferences in affirmative action programs. ${ }^{4}$ This recognition that

$\dagger$ B.A. 1992, Denison University; J.D. 1997, The University of Chicago.

See, for example, Richard D. Kahlenberg, Getting Beyond Racial Preferences: The Class-Based Compromise, 45 Am U L Rev 721, 721 (1996) ("If you ask Americans whether it is time to get beyond racial preferences, the vast majority will say yes.") (citations omitted); Abigail Thernstrom, Voting Rights: Another Affirmative Action Mess, 43 UCLA L Rev 2031, 2031-32 \& n 3 (1996) (summarizing Gallup polls showing that between 10 and 11 percent of those surveyed favor preferential treatment for minorities); Kimberly Paap Taylor, Note, Affirmative Action for the Poor: A Proposal for Affirmative Action in Higher Education Based on Economics, Not Race, 20 Hastings Const L Q 805, 808 (1993) (stating that reverse discrimination against white men merits concern, and that the stigma of "questionable confidence" in African-Americans is a pervasive problem resulting from race-based affirmative action programs).

2515 US 200, 227 (1995).

3 Id at 237 ("The unhappy persistence of both the practice and the lingering effects of racial discrimination against minority groups in this country is an unfortunate reality, and government is not disqualified from acting in response to it.").

- See id at 237-38 (considering the availability of race-neutral alternatives in deter- 
racial discrimination still exists, coupled with a political environment that is increasingly inhospitable to race-based affirmative action programs, has led scholars and legislators to consider alternatives.

"Class-based" preferences grounded on socioeconomic disadvantage are such an alternative. ${ }^{5}$ Advocates sympathetic to this approach assert that class-based preferences offer many advantages over race-based preferences from both policy and constitutional standpoints. ${ }^{6}$ As such, class-based preferences have been portrayed as a viable alternative to race-based affirmative action preferences.

The Court's suggestion, however, should sound suspicious. By encouraging the use of race-neutral alternatives to what is

mining a law's constitutional legitimacy). See also City of Richmond v J.A. Croson Co, 488 US 469, 507 (1989) (stating that one flaw of Richmond's minority contracting plan was the failure to consider race-neutral alternatives, and citing United States $v$ Paradise, 480 US 149,171 (1987), for the proposition that the "efficacy of alternative remedies" is a benchmark in evaluation of race-conscious remedial programs).

5 For an example of a class-based preference enacted into federal law, see the applicable provisions addressed in Adarand, 515 US at 206-10. These provisions are described more thoroughly in Section I. Such preferences and provisions can be expected to proliferate given their increased popularity with both courts and the public. The recent passage of Proposition 209 in California, prohibiting consideration of race as a basis for governmental preference, will surely lead some to consider class-based alternatives. See V. Dion Haynes, Who Affirms King's Dream?: 2 Civil Rights Groups Contest Means to Redress Bias, Chi Trib 11 (Feb 9, 1997) (noting support of class-based preferences by proponents of Proposition 209). In response to the Fifth Circuit's ruling in Hopwood v University of Texas, 78 F3d 932 (5th Cir 1996), the Texas Higher Education Coordinating Board has "expressed hope that state admissions and financial aid programs could continue to reach blacks and Hispanics in large numbers by changing program language to accommodate the new law." Todd Ackerman, Leap backward' in minority enrollment feared under new criteria, Hou Chron 40, 40 (Jan 17, 1997).

Recent commentary arguing for class-based preferences includes Richard D. Kahlenberg, The Remedy: Class, Race, and Affirmative Action 83-180 (Basic 1996); Kahlenberg, $45 \mathrm{Am}$ U L Rev at 721, 724-28 (cited in note 1); Richard H. Fallon, Jr., Affirmative Action Based on Economic Disadvantage, 43 UCLA L Rev 1913, 1916 (1996) (arguing for narrowly tailored affirmative action programs for the economically disadvantaged, but noting that they are a poor surrogate for racially conscious programs); Jennifer M. Russell, The Race/Class Conundrum and the Pursuit of Individualism in the Making of Social Policy, 46 Hastings L J 1353 (1995); Paul Brest and Miranda Oshige, Affirmative Action for Whom?, 47 Stan L Rev 855, 897-98 (1995); Krista L. Cosner, Note, Affirmative Action in Higher Education: Lessons and Directions from the Supreme Court, 71 Ind L J 1003, 102628 (1996); Taylor, Note, 20 Hastings Const I Q at 805 (cited in note 1); Don Munro, Note, The Continuing Evolution of Affirmative Action Under Title VII: New Directions After the Civil Rights Act of 1991, 81 Va L Rev 565, 601-09 (1995).

6 Some asserted policy advantages include being less divisive to society as a whole, less unfair to "innocent victims," and less stigmatizing to beneficiaries. See, for example, Kahlenberg, The Remedy at 42-80 (cited in note 5) (asserting that racial preferences have not achieved the goals of "genuine equality of opportunity," since under the current system wealthy blacks can receive preferences over poor non-blacks; the goal of "color-blindness" has been subverted to that of "diversity"; and these programs have led to increased racial tension and prejudice). See also note 5. 
primarily a race-based problem, the Court seems to imply that the government can do covertly what it cannot do overtly. On the other hand, the Court has expressly prohibited this type of covert manipulation, or "subterfuge." And in a series of recent cases, the Court has prohibited the government from engaging in such subterfuge in redistricting - another equal protection context. Yet despite these prohibitions, the Court appears to be condoning just such "subterfuge" in the affirmative action context.

This Comment contends that, despite the developing enthusiasm for class-based preferences, the Court's recent redistricting cases, Miller $v$ Johnson, ${ }^{8}$ Shaw v Hunt ("Shaw II"), ${ }^{9}$ and Bush $v$ Vera, ${ }^{10}$ suggest that such subterfuge is unconstitutional in affirmative action programs as well. In these redistricting cases, the Court employed a two-step analysis that can be extended to the affirmative action context. First, the Court characterized certain facially neutral legislation as racially motivated, or "covert," discrimination. ${ }^{11}$ The Court then applied the principle against subterfuge to subject this legislation to strict scrutiny review. ${ }^{12}$ In this way, the Court has indicated that legislation that appears to be covert affirmative action will be reviewed as overt discrimination. This analysis has serious implications for the viability of

7 The "principle against subterfuge" is a principle of discrimination law: a facially neutral law impermissibly motivated by racial discrimination is a subterfuge. Strict scrutiny is applied to such laws to root out discriminatory motivations. Although it is usually attributed to Washington $v$ Davis, 426 US 229 (1979), the prohibition on subterfuge derives from Gomillion v Lightfoot, 364 US 339 (1960). In Gomillion, the Court reviewed a challenge by the black citizens of Tuskegee, Alabama, to that state's redrawing of the Tuskegee city limits. Id at 340 . The plaintiffs alleged that the state's facially neutral action was motivated by a desire to exclude from the city, and consequently disenfranchise, only the city's black citizens. The plaintiffs argued that the effect of this action was unconstitutional racial discrimination. Id at 341 . The Court concluded for the first time that facially neutral action, when motivated by discriminatory intent, should be reviewed as overt discrimination. In Washington $v$ Davis, 426 US 229, the Court further defined the principle, holding that, when alleging racial discrimination a plaintiff must show that lawmakers acted with the intent to discriminate. Id at 238-39.

8115 S Ct 2475 (1995).

9116 S Ct 1894 (1996).

${ }^{10} 116$ S Ct 1941 (1996).

${ }^{11}$ In each of these cases, the Court examined a state legislature's attempt to redress the racial imbalance in that state's voting districts pursuant to the Voting Rights Act. Section 5 of the Voting Rights Act of 1965, Pub L No 89-110, 79 Stat 437, codified at 42 USC $\S$ 1973c (1994), provides that in order to prevent intentional minority vote dilution, a state making changes to its voting districting lines must have the applicable plans pre-cleared by the Department of Justice or the United States District Court for the District of Columbia. See Miller, $115 \mathrm{~S} \mathrm{Ct}$ at 2483. Despite the fact that none of the districting statutes at issue in these cases contained any express racial classification, the Court, applying the anti-discrimination principle against subterfuge, treated the facially neutral statutes as if they used the words "black" or "race." See Section II.

${ }^{2}$ See, for example, Miller, $115 \mathrm{~S}$ Ct at 2487-90. 
class-based affirmative action preferences intended to be a mere subterfuge for their unpopular race-based cousins. ${ }^{13}$

This Comment analyzes the implications of applying the principle against subterfuge to class-based preferences. Section I traces the history of affirmative action analysis and examines the viability of class-based preferences before the redistricting cases. Section II then argues that the rationale underlying the redistricting cases grafts the principle against subterfuge onto affirmative action doctrine. Section III considers the effects of applying the principle against subterfuge to affirmative action.

\section{AFFIRMATIVE ACTION DOCTRINE BEFORE THE REDISTRICTING CASES}

Before the recent redistricting cases, affirmative action measures reviewed by the Court usually consisted of explicit racial preferences, to which the Court was generally hostile. ${ }^{14}$ One

${ }^{13}$ It is important to distinguish between two types of class-based preferences. First, there are those that are intended as tactical substitutes for race-based preferences. These preferences, as attempts to accomplish covertly what is overtly impermissible, are subterfuges. Other class-based preferences motivated purely by socioeconomic concerns should not be classified as subterfuge. However, given the Court's hostility toward racial preferences, even the "pure" class-based preferences are vulnerable to at least the inference of subterfuge. Thus, "class-based preferences" as used in this Comment refer to those preferences that are vulnerable to an inference of subterfuge, and thus subject to strict scrutiny review, regardless of actual legislative intent.

${ }^{14}$ In Regents of the University of California $v$ Bakke, 438 US 265 (1978), the Court reviewed a state higher education admission-preference program under which the applications of certain identified minority groups were reviewed according to different criteria than those of other applicants, and a certain number of spots in the medical school class were reserved for those minority applicants. The Court applied heightened scrutiny to the program despite the state's claim that it was a benign classification. Id at 287-91 ("Racial and ethnic distinctions of any sort are inherently suspect and thus call for the most exacting judicial examination."). Although the Court struck down the program at issue, a plurality nevertheless recognized that "the State has a substantial interest [in eliminating the effects of past, identified discrimination, supported by proper findings] that legitimately may be served by a properly devised admissions program." Id at 320 .

Two years later, in Fullilove v Klutznick, 448 US 448 (1980), the Court upheld, under heightened scrutiny, a set-aside program reserving a certain amount of federal funds for minority-owned businesses upon congressional findings of present effects of past societal discrimination. Id at 477-78. The two factors critical to upholding the program were, first, that the program was enacted pursuant to Congress's broad remedial powers under the Fourteenth Amendment, id at 483 , and second, that the set-aside was flexible and could be waived, id at 488 .

In City of Richmond $v$ J.A. Croson Co, 488 US 469 (1989), the Court retreated from allowing past societal discrimination to serve as a sufficiently substantial governmental interest. After determining that strict scrutiny applies to all race-based action by state and local governments, id at 493 , the Court invalidated Richmond's contracting set-aside program, finding that the city had neither considered any race-neutral alternatives, nor identified with sufficient specificity the past discrimination that it was trying to ameliorate. Id at 507-08. 
manifestation of this hostility was the Court's repeated emphasis on race-neutral alternatives to race-based preferences. ${ }^{15}$ The Court thus appeared to suggest that, although explicit affirmative action was not permissible, disguised affirmative action might be. ${ }^{16}$

In following this suggestion, policymakers have disguised racially motivated preferences by substituting socioeconomic disadvantage for racial identity as the basis for the preference. ${ }^{17}$ One benefit of this strategy is to ensure that such preferences are subject to a lower standard of judicial review; advocates of classbased preferences argue that because race does not inspire the classification, courts will not apply strict scrutiny to class-based preferences. Another benefit of class-based preferences is to ease the political and societal tensions triggered by racial preferences. ${ }^{18}$ Given these two conspicuous benefits, it is reasonable to

In Adarand, the Court extended the holding in Croson, announcing that strict scrutiny review applies to all federal, as well as state and local, government affirmative action preferences and other classifications based on race. 515 US at 225-27. The Adarand Court overruled the portion of its previous decision in Metro Broadcasting, Inc v FCC, 497 US 547, 564-65 (1990), which had held that congressionally mandated "Benign" affirmative action preferences would be subject only to intermediate scrutiny. Adarand, 515 US at 237-38.

${ }^{15}$ See Croson, 488 US at 509-10 ("Even in the absence of evidence of discrimination, the city has at its disposal a whole array of race-neutral devices . . . ."); Adarand, $115 \mathrm{~S}$ Ct at 2118 (indicating importance of consideration of race-neutral alternatives as a factor in determining legitimacy of race-based presumptions). Indeed, Professor Thernstrom has characterized the Court's skepticism of race-conscious remedies implicit in the Croson opinion as a "hint of things to come." Thernstrom, 43 UCLA L Rev at 2056-57 (cited in note 1).

${ }^{16}$ Doctrinally, the importance of the historical development of affirmative action law as evidence of subterfuge should not be overlooked. The Court has focused increasing attention on state consideration of race-neutral alternatives to race-based preferences, which serves the same signaling role in the affirmative action context that bizarrely shaped districts serve in the voting rights context; the first signal that a class-based preference involves subterfuge is the Court's emphasis on consideration of race-neutral alternatives. See note 4. Indeed, the Court has expressly declared that this historical development is significant. Arlington Heights $v$ Metropolitan Housing Dev Corp, 429 US 252, 267 (1977). Thus, the historical development of affirmative action demands an inquiry into drafters' intentions.

${ }^{17}$ See text accompanying notes 5-6.

${ }^{18}$ Several commentators have recognized the correlation between courts' increasing skepticism of racial preferences and the legal "escape hatch" provided by class-based preferences. See, for example, Richard D. Kahlenberg, Class, Not Race, New Republic 21, 24 (April 5, 1995) ("The strict scrutiny that struck down Jim Crow is now used, to varying degrees, to curtail racial preferences. Class, on the other hand, is not one of the suspect categories under the Fourteenth Amendment, which leaves class-based remedies much less assailable."); Fallon, 43 UCLA L Rev at 1947 (cited in note 5) ("As a result of recent constitutional and political assaults, many existing affirmative action programs may be threatened with obliteration, and patterns of distribution that have grown familiar may be about to change profoundly. Under these circumstances, some advocates appear to regard economically based affirmative action as the best available surrogate for race-based af- 
presume that some policymakers will be influenced by this reasoning and develop affirmative action strategy accordingly.

The difficulty with this strategy is that if the "race-neutral" preference appears to be motivated by a desire to benefit racial minorities, it is open to a subterfuge challenge. If a plaintiff could raise an inference of racial motivation, even "pure" class-based preferences could be subject to such a challenge. ${ }^{19}$ Of course, once policymakers recognize this vulnerability, they may well deny any racial motivation behind the preference. While it is possible that a class-based preference might only reflect concern for the economically disadvantaged, such preferences may be open to an accusation of racial motivation, especially because the Court has suggested that race-based preferences could be disguised in such a manner. ${ }^{20}$ Indeed, in light of research demonstrating the links between the "economic underclass" and racial minorities, ${ }^{21}$ it will be difficult to contend that any socially conscious policy maker, in drafting class-based preferences, was unaware of the effects that such preferences would have on racial minorities. ${ }^{22}$

The Court's treatment of the Subcontracting Compensation Clause program at issue in Adarand Constructors, Inc v Pena ${ }^{23}$

firmative action."). See also Taylor, Note, 20 Hastings Const L $Q$ at 817-18 (cited in note 1) (advocating class-based preferences and suggesting that the Court will not apply strict scrutiny).

${ }^{19}$ Although this Comment contends that all class-based preferences could be vulnerable to an inference of subterfuge, and thus could be challenged on that ground, this Comment does not suggest that all such preferences are in fact subterfuge. See note 15.

${ }^{20}$ See note 15. Further, although he did not write the majority opinion in Croson, Justice Scalia's position on race-neutral alternatives is noteworthy. He contends that raceneutral programs are the only appropriate remedy for past, identified racial discrimination, writing: "While most of the beneficiaries might be black, neither the beneficiaries nor those disadvantaged by the [race-neutral] preference would be identified on the basis of their race." Croson, 488 US at 526 (Scalia concurring) (emphasis omitted). Justice Scalia further stated that such subterfuge was constitutionally permissible: "Since blacks have been disproportionately disadvantaged by racial discrimination, any race-neutral remedial program aimed at the disadvantaged as such will have a disproportionately beneficial impact on blacks. Only such a program, and not one that operates on the basis of race, is in accord with the letter and the spirit of our Constitution." Id at 528 (latter emphasis added). This Comment takes the position that, whether or not such subterfuge was constitutional when Justice Scalia authored this opinion, it is unconstitutional today.

${ }^{21}$ See generally William Julius Wilson, The Truly Disadvantaged: The Inner City, the Underclass, and Public Policy (Chicago 1987). See also Kahlenberg, 45 Am U L Rev at 724 (cited in note 1) ("As a result of slavery and segregation, blacks remain disproportionately poor and would disproportionately benefit from a class-based preference to the extent that the economic legacy of the past remains."); Brest and Oshige, 47 Stan L Rev at 877-78 (cited in note 5) ("As a group, African Americans lag behind whites in socioeconomic status and education.").

2 As long as there is a suggestion that such "race-neutral" preferences were motivated in part by a desire to assist racial minorities, the preference will be vulnerable to a "mixed motives" challenge. See text accompanying notes 79-86.

${ }^{23} 515$ US 200, 212-13 (1995). 
illustrates the success of the race-neutral strategy prior to the redistricting cases. In Adarand, the Court reviewed a narrow provision of a subcontracting compensation scheme generally based on disadvantage.$^{24}$ Pursuant to policies and definitions embodied in the Small Business Act, ${ }^{25}$ Department of Transportation regulations ${ }^{26}$ directed that a certain percentage of federal contracting funds "be expended with small business concerns owned and controlled by socially and economically disadvantaged individuals." The contract at issue in Adarand offered financial incentives to the prime contractor to award subcontracts to disadvantaged firms. The Court accepted the government's argument that this overall scheme was based on disadvantage, not race, stating that "[t]o the extent that the statutes and regulations involved in this case are race-neutral, we agree. ${ }^{228}$ However, the regulations further provided that certain groups were to be presumed disadvantaged, ${ }^{29}$ thus presenting a race-based classification..$^{30}$

The government argued that the rebuttable presumption of disadvantage should be subject to intermediate-level review ${ }^{31}$ as a

24 Id at 206.

${ }^{25}$ Pub L No 85-536, 72 Stat 384, codified at 15 USC $\$ \$ 631$ et seq (1994 \& Supp 1996).

${ }_{26}$ The Department of Transportation regulations are comprehensive. The specific provisions that incorporate the Small Business Act's policy of encouraging government contracting with small and minority-owned businesses and that are most relevant in Adarand include 13 CFR $\$ \S 124.102$ (1995); 124.105(b)(1) (1997); 124.106(b) (1990); 48 CFR $\$ 19.001,19.703(\mathrm{a})(2)$ (1995). For an overview of these regulations, see Adarand, 515 US at 206-10. The Court found that the applicable regulations were modeled after sections 8 (a) and 8(d) of the Small Business Act, codified at 15 USC $\$ \S 637(a), 644(a)$, both of which provided that a prime contractor who hired a subcontractor who qualified as "socially and economically disadvantaged" was entitled to a financial bonus of a portion of the total subcontract amount; that under the regulations, certain minority groups were presumed to be socially disadvantaged; that after social disadvantage was demonstrated, in most circumstances the firm independently had to prove economic disadvantage; and that the disadvantage was rebuttable by third parties offering evidence to the contrary.

${ }^{27}$ Adarand, 515 US at 208, quoting Surface Transportation and Uniform Relocation Assistance Act of 1987, Pub L No 100-17, 101 Stat 132-45 (1987).

515 US at 213.

${ }^{29}$ The appropriate level of equal protection review to be afforded to this aspect of the compensation program was the actual issue under review in Adarand. Id.

${ }^{30}$ Id. Specifically, the race-based rebuttable presumption at issue provided that "the contractor shall presume that socially and economically disadvantaged individuals include Black Americans, Hispanic Americans, Native Americans, Asian Pacific Americans, and other minorities, or any other individual found to be disadvantaged by the [Small Business] Administration pursuant to section 8(a) of the Small Business Act." Id at 205 (statutory citations omitted).

${ }^{31}$ See Metro Broadcasting, Inc v FCC, 497 US 547, 564-65 (1990) (The Court held that a "benign" federal racial classification is constitutional so long as it serves important government objectives and is substantially related to achievement of those objectives. This standard of review is known as "intermediate review."). In resolving this issue against the government in Adarand, the Court overruled this portion of Metro Broadcasting. Adarand, 515 US at 227 ("To the extent that Metro Broadcasting is inconsistent with [the] 
"benign" racial classification. ${ }^{32}$ The Court, however, concluded that all government classifications based on race, whether "benign" or invidious, are subject to strict scrutiny. ${ }^{33}$ This conclusion, coupled with dicta stating that programs based on disadvantage generally would only be subject to relaxed scrutiny ${ }^{34}$ highlights the importance of race-neutral alternatives prior to the redistricting cases.

Following this dicta in Adarand, advocates argued that properly drafted class-based preferences would be "race-neutral" ways to accomplish the same goals as race-based affirmative action..$^{35}$ Their reasoning assumed that there is a correlation between minorities and lower socioeconomic class. ${ }^{36}$ Thus, the result of these race-neutral preferences would be essentially the same as that of race-based preferences; they would assist minorities who have traditionally benefited from race-based preferences. Class-based preferences would thus remedy the problems of the "underclass" by shifting the focus of affirmative action away from race and towards a broader notion of socioeconomic disadvantage. ${ }^{37}$

The perceived advantage of class-based preferences is that they would not be plagued by the policy conflicts and constitutional infirmities that result from a focus on race. ${ }^{38}$ Indeed, before the Court's redistricting opinions, the viability of class-based preferences seemed relatively straightforward. Because the economically disadvantaged are not a suspect class under equal protection doctrine, such preferences would have been subject to lower-level equal protection review. ${ }^{39}$

holding [that all racial classifications are subject to strict scrutiny], it is overruled.").

32 Brief for Respondents, Adarand, No 93-1841, 1994 WL 694992 at *38-40.

${ }^{33}$ Adarand, 515 US at 227.

${ }^{34}$ Id at 212-13 ("The Government urges that " $[t]$ he Subcontracting Compensation Clause program is ... a program based on disadvantage, not on race,' and thus that it is subject only to the most relaxed judicial scrutiny.") (citation omitted). See also text accompanying note 28 .

${ }^{35}$ See notes 5-6.

${ }^{36}$ See note 21.

${ }^{37}$ See Kahlenberg, The Remedy at 101 (cited in note 5) (asserting that while the main goal of class-based preferences is to provide "genuine equal opportunity," class-based preferences would result in "compensation for past discrimination, the benefits of racial integration, and a color blind future").

${ }^{38}$ See Taylor, Note, 20 Hastings Const L Q at 817-19 (cited in note 1). See also Munro, Note, $81 \mathrm{Va}$ L Rev at 608 (cited in note 5).

${ }^{9}$ San Antonio Independent School District v Rodriguez, 411 US 1, 28-29 (1973). 


\section{THE REDISTRICTING CASES: IMPORTING THE PRINCIPLE AGAINST SUBTERFUGE INTO AFFIRMATIVE ACTION LAW}

When the principle against subterfuge-the rationale underlying the redistricting cases-is applied in the affirmative action context, some facially neutral government action is recast as overt racial discrimination. This application means that whenever the Court suspects a racial motivation behind an ostensibly neutral statute, the principle against subterfuge will prohibit the government from doing covertly what it may not do overtly. Thus, a litigant challenging a class-based preference after the redistricting cases has a strong argument that such a preference is mere subterfuge, and should be reviewed under strict scrutiny. ${ }^{40}$ Indeed, in Adarand, the Court expressly reserved questions concerning the "additional [constitutional] difficulties posed by laws that, although facially neutral, result in disproportionate impact and are motivated by a racially discriminatory purpose. ${ }^{31}$ After the redistricting cases, class-based preferences squarely present these unanswered questions.

That the principle against subterfuge extends to affirmative action follows from Miller, ${ }^{42}$ Shaw $I I,{ }^{43}$ and Vera. ${ }^{44}$ Each of these redistricting cases, which recharacterized a covert legislative scheme (compliance with the Voting Rights Act) as an overt racial classification, used the principle against subterfuge to subject such legislation to strict scrutiny. ${ }^{45}$

The Court created the analytical framework for these redistricting challenges in Shaw $v$ Reno ("Shaw I"). ${ }^{46}$ In Shaw I, the Supreme Court created a new cause of action under the Equal Protection Clause ${ }^{47}$ permitting a plaintiff to challenge a state's redistricting legislation if the plan, "on its face, rationally could not be understood as anything other than an effort to separate

10 This Comment contends that before the redistricting cases, the subterfuge argument was unavailable to challengers of class-based preferences; before these cases, there was no precedent to apply the principle against subterfuge to facially neutral affirmative action. The application of the principle in the redistricting cases provides such precedent.

4515 US at 213 (citations omitted).

515 US 900 .

116 S Ct 1894.

* 116 S Ct 1941.

${ }^{45}$ See text accompanying notes 50-73. Furthermore, at least one scholar has recognized the link between race-based preferences in the redistricting context and affirmative action. See Thernstrom, 43 UCLA L Rev at 2031 (cited in note 1) ("The point of the raceconscious districting in Texas, for instance, was precisely that of most affirmative action policies: to provide maximum protection for minority candidates from white competition.").

${ }^{45} 509$ US 630 (1993).

${ }^{47}$ US Const, Amend XIV, § I. 
voters into different districts on the basis of race."188 Thus in Shaw $I$, the Court provided that facially neutral legislation, passed in an effort to comply with the affirmative action provisions of the Voting Rights Act (and as such, "covert" affirmative action), could be challenged on equal protection grounds after a showing of "racially motivated purpose or object. ${ }^{.49}$

In Miller, the first of the recent redistricting cases, the Court relied upon Shaw $I$ for the principle that "statutes are subject to strict scrutiny ... not just when they contain express racial classifications, but also when, though race neutral on their face, they are motivated by a racial purpose or object." ${ }^{.50}$ The Court then recalled the subterfuge principle set forth in such landmark antidiscrimination cases as Yick Wo $v$ Hopkins $^{51}$ and Gomillion $v$ Lightfoot ${ }^{52}$-if the underlying or motivating factor in facially neutral state action was racially based, then the action must be subject to strict scrutiny review no matter how that purpose is manifested. ${ }^{53}$ The Court's explicit reference to early subterfuge cases is important because it links antidiscrimination analysis with affirmative action doctrine, implying that the principle against subterfuge extends to the affirmative action context. The Court concluded that "Shaw [I] applied these same principles to redistricting. ${ }^{25}$

The link between the early subterfuge cases and affirmative action is illustrated by the Court's treatment of the state's objective in Miller-compliance with the Voting Rights Act. ${ }^{55}$ The Court recognized that, by definition, this goal required some consideration of race by the state legislators. ${ }^{56}$ The Court reasoned, however, that even under an express mandate to consider race, not all legislation taking race into consideration was consistent with the Equal Protection Clause. ${ }^{57}$ Thus, the question was whether Georgia's plan for the redrawn Eleventh District considered race impermissibly. On the basis of evidence in the case, the Court concluded that Georgia had in fact considered race impermissibly when it "subordinated traditional districting principles

13509 US at 649.

${ }^{49}$ See Miller, $115 \mathrm{~S}$ Ct at 2487.

${ }^{30}$ Id, citing Shaw I, 509 US at 644.

s1 118 US 356, 373-74 (1886).

${ }^{82} 364$ US 339, 347 (1960).

${ }^{25}$ Miller, 115 S Ct at 2487.

${ }^{s}$ Id.

${ }^{\text {ss }}$ See id at 2488.

${ }^{56}$ Id (explaining that the constitutional difference is between merely "being aware of racial considerations" and being motivated by them).

${ }^{57}$ Id. 
to race. ${ }^{958}$ The Court found that race was the "predominant, overriding factor explaining the General Assembly's decision to attach to the Eleventh District various appendages containing dense majority-black populations." ${ }^{.59}$ Because of this conclusion, the Court reviewed Georgia's plan under strict scrutiny. ${ }^{60}$

Miller thus stands for the proposition that when legitimate classifying principles are subordinated to considerations of race, the legislation will be reviewed under strict scrutiny as an overt racial classification. ${ }^{61}$ The theories motivating the Court in Miller apply equally to affirmative action. Thus, Miller suggests that class-based affirmative action preferences primarily intended to benefit racial minorities would also be subject to strict scrutiny. ${ }^{62}$

More recently, Vera and Shaw II clarified the extent to which the redistricting cases may influence affirmative action law. These cases confirmed that the principle against subterfuge will be used to subject facially neutral but racially motivated classifications to strict scrutiny. In Vera, the Court reviewed a challenge to Texas's redistricting plan. ${ }^{63}$ The Court held, as in Miller, that because the state "substantially neglected traditional districting criteria" and "manipulated district lines to exploit unprecedentedly detailed racial data," the state's action was racially motivated. ${ }^{64}$ In light of this motivation, the Court evaluated the redis-

${ }^{58}$ Id at $2489-90$.

${ }^{59}$ Id at 2490. The Court explained that "traditional districting principles" included the following considerations: "compactness, contiguity, respect for political subdivisions or communities defined by actual shared interests." Id at 2488 .

${ }^{60}$ Id at 2490 . The Court relied on the following evidence in order to make the finding that the state had indeed subordinated traditional districting principles to race: that the shape of the district, when considered in relation to "racial and population" densities, was irregular; that the state was complying with the Justice Department's policy of "maximization" of minority districts; and that the state's "alternative explanations" were disingenuous given the substantial evidence to the contrary. Id at 2488-90.

${ }^{61}$ Id at 2490. The Court in Miller reiterated the principle that, in order to pass muster under strict scrutiny, the districting legislation must be narrowly tailored to accomplish a compelling governmental purpose. Id. The Court rejected the state's argument that under a proper reading of the statute, complying with the Department of Justice's mandates under the Voting Rights Act was, in and of itself, a compelling governmental interest. Id at 2491.

\&2 The following question thus emerged: How racially motivated does a class-based preference have to be before it is subject to a subterfuge problem? If the standard for evaluating affirmative action cases tracks the Miller standard, then race must be "the predominant, overriding factor" behind the preference. Id at 2490 . This high standard would leave open the possibility that a lesser degree of racial motivation might be acceptable. See text accompanying notes 73-89.

${ }^{53} 116 \mathrm{~S} \mathrm{Ct}$ at 1950-51.

6s Id at 1953. In reaching its conclusion, the Court drew an instructive distinction between the constitutional goal of "political gerrymandering" (including consideration of "political data" such as election voting patterns and "legislators' experience"), and the impermissible goal of "racial gerrymandering," which occurs when a state uses race as a 
tricting plan under strict scrutiny. ${ }^{65}$ It found, based on a variety of evidence, ${ }^{66}$ that the state had subordinated traditional districting principles to racial considerations. ${ }^{67}$ Again, this case illustrates, as did Miller, the expansive potential of strict scrutiny review in the affirmative action context.

In Shaw II, the Court defined what constitutes an "insufficiently compelling governmental interest" under strict scrutiny review. ${ }^{68}$ North Carolina offered three governmental interests as sufficiently compelling to justify its redistricting plan: one remedying the effects of discrimination and two concerning compliance with the Voting Rights Act. ${ }^{69}$ In its analysis of the remedial justification, the Court held that, although eliminating discrimination could be a sufficiently compelling governmental interest in redistricting, it could not be sufficiently compelling when the discrimination alleged was not specific and identified, and the evidence did not indicate the necessity of such a remedy ${ }^{70}$ With respect to the Voting Rights Act justifications, the Court determined that a "maximization" of black voting strength is not a compelling interest under the Act, ${ }^{71}$ and that, even if compliance with the Act were a compelling interest, the remedy was not tailored narrowly enough given the facts of the case. ${ }^{72}$ Shaw II thus highlights the boundaries of what the Court considers a sufficiently compelling governmental interest under strict scrutiny review. Given the rigorous standards of the Court's analysis in the redistricting cases, this Comment contends that courts reviewing class-based preferences under strict scrutiny would apply similar rigorous standards.

Ironically, this extension of the principle against subterfuge into the affirmative action context has emerged simultaneously with the growing popularity of class-based preferences as an alternative to race-based affirmative action. ${ }^{73}$ Because class-based

\footnotetext{
"proxy for political characteristics" that results in "racial stereotyp[ing] requiring strict scrutiny." Id at 1956.

${ }_{65} \mathrm{Id}$ at 1953.

${ }^{66}$ The Court considered the explicit language of the state's Voting Rights Act Section Five submission, id at 1956-57; testimony of state officials regarding the consideration of race, id at 1957; and "objective evidence provided by the district plans and demographic maps." Id.

"Id at 1957-58.

${ }^{6 s} 116 \mathrm{~S} \mathrm{Ct}$ at 1901.

${ }^{6}$ Id at 1902.

${ }^{20}$ Id at 1902-03.

${ }^{71} \mathrm{Id}$ at 1904.

${ }^{72}$ Id at 1905-06.

${ }^{73}$ See note 5.
} 
preferences may prove to be as constitutionally problematic as race-based preferences, they must be reevaluated.

\section{APPLYING THE PRINCIPLE AgAINST SUBteRfuge TO AFFIRMATIVE ACTION}

If the redistricting cases extended the principle against subterfuge into the affirmative action context, then strict scrutiny will be applied to review preferences under an equal protection challenge based on claims of discriminatory intent. This application of the principle against subterfuge to affirmative action analysis would raise two important questions. First, how does the principle actually work in application? Second, should the principle be applied to the same extent in affirmative action cases as in discrimination cases?

\section{A. Contours of the Principle Against Subterfuge in Affirmative} Action Analysis

If facially neutral affirmative action schemes are subject to an equal protection challenge on the grounds of discriminatory intent, it follows that a government instituting a class-based preference may have to demonstrate that the preference is not racially motivated. The result is that to survive strict scrutiny review, facially neutral affirmative action preferences must avoid revealing an intent to benefit racial minorities. Conversely, to obtain strict scrutiny review, a litigant challenging such a preference must be able to offer evidence of impermissible racial motivation.

The weight of this evidentiary burden will vary depending on whether the challenged preference is a "pure" one, or whether it is in fact subterfuge. As previously noted, supporters of classbased preferences fall into two categories: those who explicitly advocate such preferences as an alternative means to a racebased end, and those who suggest instead that socioeconomic class is a more legitimate means of achieving distributive justice. $^{74}$ Class-based preferences designed by the latter group should not be vulnerable to a subterfuge challenge; if truly intended to accomplish distributive justice by considering only the

\footnotetext{
${ }^{74}$ Professor Fallon has recognized this dichotomy. He divides class-based supporters into two groups: first, those who advocate class as a surrogate or substitute for race in the face of a legally and politically hostile environment, and second, those who support class preferences as better serving the goal of distributive justice. See Fallon, 43 UCLA L Rev at 1914-15 (cited in note 5).
} 
beneficiaries' socioeconomic class, then these preferences should survive.

Class-based preferences established by the former group are clearly more vulnerable to strict scrutiny review. Such preferences are also vulnerable to a subterfuge challenge because a politically motivated desire to find a "compromise" means to achieve affirmative action goals serves as strong evidence of subterfuge. ${ }^{75}$ The success of any individual challenge, however, will depend on the strength of the evidence of racial motivation.

Courts considering a subterfuge challenge have two models for reviewing allegedly impermissible racial motivations. One is the model used in the redistricting cases; the other is the model used in the related employment discrimination context. Neither model fits perfectly with the affirmative action context, ${ }^{76}$ but each offers a possible tool for evaluating evidence of racial motivations.

In Miller, the Court concluded that three principal pieces of evidence, when considered together, carried the plaintiff's burden and established racial motivation: first, the circumstantial evidence of the district's shape; second, "relevant racial demographics"; and third, the Justice Department's refusal to preclear the district under the Voting Rights Act unless the district sufficiently "maximized" black voting strength. ${ }^{77}$ Although it is unclear whether any single factor was either necessary or sufficient

${ }^{75}$ With the possible exceptions of Kahlenberg and Fallon, all of the commentators reviewed in this Comment advocate this rationale for class-based preferences. A typical example of this position is: "Because of the inherent costs of affirmative action and because of the controversy it provokes, programs which revamp existing affirmative action programs or race-neutral programs that achieve similar goals should be vigorously pursued." Cosner, Note, 71 Ind L J at 1026 (footnote omitted) (cited in note 5). As for the possible exceptions, Fallon's view is that class-based preferences, justified on grounds of moral justice and social utility, are a good idea, but only if drawn narrowly. See Fallon, 43 UCLA L Rev at 1916 (cited in note 5). However, Fallon is "puzzle[d]" by the idea that class is a good "surrogate" for race. He finds such a surrogate, whether motivated by purely tactical reasons or by a general dissatisfaction with race as a sorting characteristic, unnecessary and dishonest. Id at 1947-50.

It is unclear which type of preferences Kahlenberg advocates. In his book, he seems to argue for class-based preferences on their own merits, yet claims that the preferences will accomplish the original goals of early affirmative action programs. See note 5. Further, some of his other writings seem to suggest a subterfuge motivation. See notes 1 and 88 .

${ }^{76}$ First, the analysis in the redistricting cases entails a threshold inquiry over the proper level of review which, according to this Comment, is inapplicable. Because of the historical development of class-based preferences, this Comment argues that even "pure" class-based preferences will raise an inference of racial motivation. This inference will in turn trigger strict scrutiny. This strict scrutiny review will reveal whether or not the preference is in fact subterfuge.

In the employment discrimination context, review is conducted under Title VII, which is inapplicable in this context.

n Miller, 115 S Ct at 2488-89. 
to support its conclusion, the Court placed a good deal of significance on the preclearance process between Georgia and the Justice Department. Certain communications during this process indicated that the Justice Department's requirements for preclearance required Georgia to violate "traditional districting principles. ${ }^{\text {78 }}$

The Court confronted this same issue in Vera, which it characterized as a "mixed motives" case ${ }^{79}$ In order to defend its legislation, Texas admitted that an explicit goal was to create a majority-minority district. ${ }^{80}$ However, it argued that there were other, permissible motivations, such as the protection of incumbents. ${ }^{81}$ In evaluating this justification, the Court considered the Texas legislature's respect for "traditional districting principles," the legislature's stated motivations, and further evidence deduced from the legislature's methodology in drawing the new district lines. ${ }^{82}$ While the Court did not provide a specific formula for weighing these "mixed motives," it found that illegitimate racial considerations were the predominant motivation.

The Court also addressed this "mixed motives" issue in Price Waterhouse $v$ Hopkins, ${ }^{83}$ an employment discrimination case. It held that when an employee alleges that both legitimate and illegitimate, or "mixed," motivations influenced an employment decision, if the employer can show that it would have made the same decision in the absence of the illegitimate motivation, the employer will not be held liable for discrimination under Title VII. ${ }^{84}$ In reaching its conclusion that an employer could avoid liability by demonstrating a sufficient legitimate motive, the Court stated that it did not "traverse new ground." ${ }^{\text {"85 }}$ Specifically, the Court noted that it had reached "a similar conclusion in other contexts where the law announces that a certain characteristic is irrelevant to the allocation of burdens and benefits. ${ }^{386}$

78 "Georgia's Attorney General objected to the Justice Department's demand for three majority-black districts on the ground that to do so the State would have to violate all reasonable standards of compactness and contiguity.' This statement from a state official is powerful evidence that the legislature subordinated traditional districting principles to race ...." Id at $2489-90$ (citation omitted).

$116 \mathrm{~S} \mathrm{Ct}$ at 1952.

${ }^{80} \mathrm{Id}$.

si Id.

${ }^{82}$ Id at 1952-54.

§ 490 US 228 (1989).

ss Id at 252-53.

s5 Id at 248.

${ }^{86}$ Id, citing Mount Healthy Board of Education v Doyle, 429 US 274, 285-86 (1977) (stating that Board of Education should have had the chance to show that it would not have rehired plaintiff regardless of conduct protected by the First Amendment); Arlington, 
If the Court were to adopt a similar approach in evaluating the motives behind class-based preferences, class would be a legitimate classification, even if race were a consideration in this classification, so long as the government could demonstrate that other valid considerations motivated its choice. ${ }^{87}$ Furthermore, if the government could prove that it would have based the preference on the same qualifying criteria even without its consideration of race, then the classification may stand.

Thus, in applying the principle against subterfuge in this context, courts could follow either of these two models-redistricting or employment discrimination-in analyzing the mixed motives issue. Both inquiries seem to ask essentially the same question, whether or not the policymakers were more heavily influenced by the legitimate or the illegitimate motives. In following either model, courts would require concrete evidence of racial motivation.

This evidence will vary depending on the context of each specific case. First, courts could infer subterfuge from the circumstantial evidence of a jurisdiction that is required by law to replace its scheme of racial preferences with a class-based scheme. Stronger evidence of subterfuge might consist of a comparative empirical analysis of the beneficiaries of the former race-based preference and the beneficiaries of the replacement, class-based preference; a nearly equivalent number of racial minorities benefiting under both schemes could suggest subterfuge. Or, in such a jurisdiction, a pattern of changes in qualifying criteria yielding a constant increase in minority beneficiaries could also suggest subterfuge.

Another source of evidence of racial motivation could be state officials' comments stating the intended goals of the class-based preferences. For example, any statements on the public record which indicate the use of socioeconomic criteria as a compromise or substitute for race-based criteria could be viewed as subterfuge. ${ }^{88}$ These comments could be found in legislative history,

429 US 252, 270-71 n 21 (1977) (applying Mount Healthy standard where the plaintiff alleged that illegitimate motivation infected enactment of legislation); Hunter $v$ Underwood, 471 US 222, 228 (1985) (same).

${ }^{87}$ Such an argument--that although race was considered, it was not illegitimatemight take either of two forms: (a) the way in which race was considered was legitimate (i.e., not discriminatory against either race); or (b) race was not the only factor considered.

${ }^{88}$ For example, consider the use of the word "compromise" in the title of the article, Getting Beyond Racial Preferences: The Class-Based Compromise. Kahlenberg, 45 Am U L Rev at 721 (cited in note 1). Indeed, the word "compromise" suggests a deal crafted to please opposing factions. Such a deal could be considered evidence of subterfuge. Furthermore, although Kahlenberg disclaims any intent to benefit racial minorities, he subtly 
newspapers, or any other public record illustrating state officials' intent. .99

\section{B. The Principle Against Subterfuge Should Apply \\ Coextensively in Both the Antidiscrimination and Affirmative Action Contexts}

There is little reason not to extend the principle against subterfuge to affirmative action. As previously noted, discrimination doctrine clearly prohibits subterfuge; the state may not employ seemingly permissible means to mask discriminatory ends. ${ }^{90}$ Discriminatory racial classifications are equally invidious, whether covert or overt. ${ }^{91}$ As overt race-based affirmative action becomes increasingly viewed as discrimination, the question becomes whether covert race-based affirmative action is constitutionally viable. ${ }^{22}$

The propriety of extending the prohibition on subterfuge depends partly on whether the practical problems associated with overt (i.e., race-based) affirmative action persist with covert (i.e., class-based) preferences. These problems include stigma and its impact on "innocent victims." This section concludes that the problems created by affirmative action persist whether the preferences are covert or overt. Thus, under the principle of equal protection, the former are as constitutionally impermissible as the latter.

frames his argument in terms of our race-based history. He notes that, "[p]roviding preferences to disadvantaged people generally is at once color-blind and cognizant of our nation's history." Id at 724. Legislators could be motivated by the same dual intentions.

${ }^{89}$ For example, after the decision in Hopwood $v$ University of Texas, 78 F3d 1465 (5th Cir 1996), which prohibited the University from using race as a factor in admissions decisions, the chairman of a state panel on demographers and sociologists was quoted in the Houston Chronicle as saying, "We cannot overcome last year's ruling by using factors other than race and ethnicity. ... There is simply no substitute for those in achieving diversity. The result won't be a step backward, it will be a gigantic leap backward." The paper reported that, "[the] panel nevertheless recommended to the [Texas Higher Education] Coordinating Board that it use . . . socioeconomic criteria, saying: 'That's the best we can come up with." The paper also reported the Chairman stating that he was "discouraged" by the demographic data but was 'not without hope' that creative solutions still can be found." Ackerman, Houston Chronicle at 40 (cited in note 5). This statement could be taken as evidence of subterfuge.

${ }^{90}$ See text accompanying notes 46-62.

${ }^{91}$ Adarand, 515 US at 240.

${ }_{22}$ See id (Thomas concurring) (noting that classifications based on race conflict with the "moral basis of the equal protection principle"). 


\section{Stigma.}

The leading argument against race-based affirmative action is that racial classifications-whether benign or invidious-are stigmatizing. ${ }^{93}$ Proponents of class-based preferences argue that legislative reliance on class, rather than race, alleviates this stigma. ${ }^{94}$ This argument assumes that racial classifications are stigmatizing, and socioeconomic classifications are not.

As the Court comes to view affirmative action as discrimination, stigma becomes more and more of a concern. According to the current Court, even purportedly benign preferences are stigmatizing. ${ }^{95}$ Justice Stevens, for example, has expressed reservations about affirmative action on this point. In his concurrence in Croson, Stevens described the "special irony in the stereotypical thinking that prompts legislation of this kind. Although it stigmatizes the disadvantaged class with the unproven charge of past racial discrimination, it actually imposes a greater stigma on its supposed beneficiaries." ${ }^{\prime 96}$ The most forceful proponent of this argument is Justice Thomas, who, in Adarand, characterized all race-based federal affirmative action programs as "paternalism" and accused members of the Court of acting on the false premise of a "racial paternalism exception to the principle of equal protection."

With its focus on a "color-blind" society, ${ }^{98}$ and on "raceneutral" classifications, ${ }^{99}$ the Court seems to imply that only racial classifications are stigmatizing. If so, "pure" class-based preferences should not be seen as stigmatizing. But if class-based preferences are perceived as a covert substitute for racial preferences, they might in fact be considered equally stigmatizing.

Proponents of class-based preferences argue that the stigmatizing effect of these preferences is minimal. For instance, Richard Kahlenberg, a leading scholar and an advocate of class-based preferences, offers two arguments in support of his claim that dif-

\footnotetext{
${ }^{93}$ See Croson, 488 US at 516-17 (Stevens concurring in part and concurring in the judgment).

${ }^{*}$ See, for example, Munro, Note, $81 \mathrm{Va}$ L Rev at 608 (cited in note 5) ("[T]he traditional arguments about 'stigma' lose much of their force when applied to class-based affirmative action.").

${ }^{95}$ See Adarand, 515 US at 228-30 (noting that the stigma of racial classifications, affecting both the group benefited and the group burdened, provides a "persuasive case" for requiring strict scrutiny of all classifications, whether "benign" or "invidious").

${ }^{9} 488$ US at 516-17 (Stevens concurring in part and concurring in the judgment).

${ }^{97} 515$ US at 240-41 (Thomas concurring in part and concurring in the judgment).

${ }^{9}$ See, for example, Shaw I, 509 US at 642, citing Plessy v Ferguson, 163 US 537, 559 (1896) (Harlan dissenting).

${ }^{99}$ See note 4.
} 
ferences between class- and race-based preferences negate any inference that the former are stigmatizing. First, he argues that class is a more legitimate criterion on which to base preferences. Second, he claims that no "myth of inferiority" attaches to class. ${ }^{100}$

Neither argument is wholly convincing. As Kahlenberg himself notes, "stigma . . . is bound up with the idea of whether a criterion is legitimate." As an example of a legitimate criterion, Kahlenberg observes that "[s]tudents with good grades aren't seen as getting in 'just because they're smart." 101 Kahlenberg asserts that there "appears to be a societal consensus that kids from poor backgrounds deserve a leg up," and that this consensus makes the criterion legitimate. ${ }^{102}$

One difficulty with this assertion is that it defines legitimacy, and thus the perception of stigma, by reference to current political whims. That is, Kahlenberg offers no normative reason why class-based preferences are more legitimate than race-based ones. He merely states that they are, and they are only because society perceives them to be. Without some normative link between the classification and the benefit that makes the benefit seem "deserved" (like the link between "students with good grades" and "admission"), then the legitimacy of the classification is subject to the whim of political popularity. And if the legitimacy is subject to political popularity, then so is the perception of stigma. Thus, from a legitimacy perspective, class-based preferences seem as vulnerable as racial preferences to the problem of stigmatization.

Even if one argues, as do some advocates of pure class-based preferences, that such preferences are grounded in independently valid normative principles, such as social utility or fairness, ${ }^{103}$ such preferences are still vulnerable to the stigma problem in two ways. First, at a very general level, any classification of individuals into groups for the purpose of offering them a preference over other individuals sacrifices individual rights for grouping principles. ${ }^{104}$ The public is likely to stigmatize any group gaining bene-

${ }^{100}$ Kahlenberg uses the language of "myth of inferiority" in other works as well. See Kahlenberg, The Remedy at 175 (cited in note 5); Kahlenberg, New Republic at 26-27 (cited in note 18). The legitimacy argument apparently stems from the position that classbased preferences are not intended as a substitute for race, but instead are independently desirable.

${ }^{101}$ Kahlenberg, New Republic at 26 (cited in note 18).

${ }^{102} \mathrm{Id}$.

${ }^{103}$ See Fallon, 43 UCLA L Rev at 1923-24 (cited in note 5).

${ }^{10}$ See Bakke, 438 US at 320 ("The fatal flaw in petitioner's preferential program is its disregard of individual rights as guaranteed by the Fourteenth Amendment. Such rights are not absolute. But when a State's distribution of benefits or imposition of burdens hinges on ancestry or the color of a person's skin, that individual is entitled to a demonstration that the challenged classification is necessary to promote a substantial state in- 
fits through a legislative preference when those benefits are perceived to be unjustified..$^{105}$ As long as there is a critic who is willing to assert that the beneficiaries do not "deserve" the preference, the preference may result in stigmatizing the beneficiaries. Class-based preferences may thus be unable to avoid the stigma associated with explicit racial classifications.

More specifically, as one scholar has noted, there is an independent "stigmatic link" between race and poverty ${ }^{106}$ which suggests that a beneficiary of a class-based preference who happened also to be black would still be plagued by stigma-even if the preference at issue was not intended to be a surrogate for race. Thus, even if the criterion of socioeconomic class were immune to stigma problems, at least among the proportion of class-based beneficiaries who are racial minorities, the stigma problem might well persist.

Kahlenberg claims that class-based preferences will not result in stigma because there is no "myth of inferiority in this country about the abilities of poor people."107 This claim, based on the existence of a myth, or the lack thereof, is difficult to prove. In fact, one could argue exactly the opposite: that in this country, wealth matters, that people associate wealth with intelligence and advantages at many levels, and that indeed, there is an inherent "myth of inferiority" attached to the poor as a group. If this is the case, then the use of class as a grouping criterion will likely generate its own brand of stigma when used as a classification for preferences. The point is not that Kahlenberg must be wrong, but rather that he is not necessarily right. Stigma could indeed result from preferences based on socioeconomic status. Indeed, class-based preferences may well be no more immune to stigma problems than race-based preferences.

\section{Impact on "Innocent Victims."}

A second problem with overt race-based affirmative action is its harm to "innocent victims."

\footnotetext{
terest.") (citation omitted).

${ }^{105}$ See Croson, 488 US at 517 (Stevens concurring in part and concurring in the judgment) ("' $[\mathrm{A}]$ statute of this kind inevitably is perceived by many as resting on an assumption that those who are granted this special preference are less qualified in some respect that is identified purely by their race."), quoting Fullilove, 448 US at 545 (Stevens dissenting); see also Bakke, 438 US at 298 (observing that "preferential programs may only reinforce common stereotypes holding that certain groups are unable to achieve success without special protection based on a factor having no relationship to individual worth").

${ }^{105}$ Fallon, 43 UCLA L Rev at 1949 (cited in note 5).

${ }^{107}$ Kahlenberg, New Republic at 26 (cited in note 18).

${ }^{108}$ See Bakke, 438 US at 298 (stating that "[n]othing in the Constitution supports the
} 
cent victims, presumably non-minorities, ${ }^{109}$ did not personally deprive racial minorities of economic and social opportunities. Nevertheless, they are now "losing" those opportunities to racial minorities. Thus, race-based affirmative action is perceived to be divisive and unfair to non-minorities. ${ }^{110}$ Seeking to avoid this perception, supporters of class-based preferences assert that if poor non-minorities benefit from class-based preferences, then the divisiveness of race as a qualifying criteria, and the unfairness objections, should subside. ${ }^{111}$

There are two main difficulties with this position. The first is that, to the extent that any preference system includes some groups and excludes others, all preferences can be expected to have divisive effects on society as a whole. This argument is a criticism of preferences generally, and the modest point here is that simply changing the beneficiary does not ameliorate the effects of exclusion on those either on the margins but ineligible for the preference, or on those who have "made it on their own" without the benefit of a preference. These excluded groups may feel hostility toward the beneficiaries, no matter what the criterion used in the scheme.

This argument takes on additional significance when applied to class-based preferences. To the extent that beneficiaries of a class-based preference scheme are racial minorities, any divisiveness that was arguably attributable to race will still be present even if the preference is covert. Thus, changing the basis of the preference would not cause these problems to disappear. Furthermore, it is difficult to identify the exact parameters of the "innocent victim" complaint. Kahlenberg argues that "white resentment" has contributed to the unpopularity of affirmative action, citing a study that found that the "mere mention' of affirmative action raises white hostility toward blacks."112 But, even then, Kahlenberg does not specify exactly what whites resent.

notion that individuals may be asked to suffer otherwise impermissible burdens in order to enhance the societal standing of their ethnic groups").

${ }^{109}$ For an interesting discussion of "innocence" in the affirmative action context, see Shelby Steele, The Content of Our Character 5 (St Martin's 1990) (arguing that the "racial struggle in America has always been primarily a struggle for innocence"); id at 6 ("To be innocent someone else must be guilty, a natural law that leads the races to forge their innocence on each other's backs. The inferiority of the black always makes the white man superior; the evil might of whites makes blacks good.").

${ }^{110}$ Kahlenberg, The Remedy at 71-74 (cited in note 5).

${ }^{111}$ Id at 117-20.

${ }^{112}$ Id at 71-72 ("When affirmative action is not mentioned in the poll question, 26 percent of whites believe that African Americans tend to be irresponsible, but when affirmative action is discussed in passing, the number climbs to 43 percent.") (citation omitted). 
Does the majority resent any minority that benefits at what is perceived to be the majority's expense? If so, then a covert preference is just as politically inadequate as an overt one.

On the other hand, if resentment occurs only when a racial minority who has not suffered from particular economic discrimination benefits at a non-minority's expense, then that resentment should logically subside if only poor minorities are entitled to preferences (i.e., if the preference is covert). Even if a nonminority loses an opportunity to another non-minority, from the fact of preference inevitably follows the perception of an "innocent victim." Because, under the Court's holdings, a preference founded on subterfuge is never principled, there is no reason to believe that the "innocent victim" problem, or the social divisiveness of such classifications, will disappear if the preference is covert as opposed to overt.

\section{CONCLUSION}

Class-based affirmative action preferences have recently received a great deal of popular support from scholars and legislators, and perhaps even the implicit approval of the Supreme Court. However, the rationale of the recent redistricting cases challenges the viability of such preferences. Those cases extend the principle against subterfuge, familiar in antidiscrimination law, into the affirmative action context. Thus, any affirmative action scheme is recast as an overt racial classification upon a showing of racially motivated intent. ${ }^{113}$ Although the Court is probably ultimately unwilling to declare all affirmative action unconstitutional, ${ }^{114}$ it will have to recognize that class-based preferences that violate the principle against subterfuge are an unconstitutional alternative to the race-based preferences it is presently denouncing.

\footnotetext{
${ }^{123}$ See Washington $v$ Davis, 426 US 229, 242 (1979) (holding that if a statute is facially neutral and rationally related to a permissible government purpose, then strict scrutiny is not applied unless the plaintiff can demonstrate that the classification was enacted for its discriminatory intent, and not merely despite a discriminatory effect).

${ }^{11}$ See note 3.
} 